\title{
Fragmentos de apocalipsis: la Guerra Civil española en Miserias de la guerra, de Pío Baroja
}

\author{
Fragments of Apocalypse: The Spanish Civil War in \\ Miserias de la guerra, by Pío Baroja
}

\author{
Mercedes Tasende \\ Western Michigan University \\ mercedes.tasende@wmich.edu \\ ORCID iD: https://orcid.org/0000-0002-7934-0758
}

\section{RESUMEN}

En Miserias de la guerra, redactada entre 1949 y 1951, Pío Baroja recurre a las convenciones del género apocalíptico para articular una visión retrospectiva de la Guerra Civil y hacer una serie de vaticinios ex eventu acerca de los resultados de esta. A diferencia de otros textos apocalípticos que conciben la Historia como una totalidad predeterminada por Dios, Baroja niega la intervención divina en los asuntos de los hombres e incide en la responsabilidad individual de los que decidieron unirse a la lucha en nombre de unas utopías religiosas o políticas. Frente a los autores de los textos apocalípticos, que interpretan la violencia y la destrucción como el inicio de la transformación cósmica, y un paso previo a la llegada de un nuevo orden en el que reinará la armonía y la paz, Baroja incide en la falsedad de todas las utopías y en la finalidad de la muerte.

Palabras Clave: Miserias de la guerra; Saturnales; novelas póstumas de Pío Baroja; Baroja y la Guerra Civil.

\begin{abstract}
In Miserias de la guerra, written between 1949 and 1951, Pío Baroja resorts to the conventions of the apocalyptic literature to articulate a retrospective vision of the Spanish Civil War and to make a series of ex eventu prophecies related to the results of the conflict. While most apocalyptic texts conceive History as a totality predetermined by God, Baroja rejects beliefs about divine intervention in the affairs of humans and insists on the individual responsibility of those who decided to join the fight in the name of religious or political utopias. While apocalypticists interpret the catastrophes and other divine punishments that devastate the world as a sign of cosmic transformation and as a first step towards the creation of a new order of justice and equity, Baroja insists on the falseness of all utopias and on the finality of death.
\end{abstract}

Key words: Miserias de la guerra; Saturnales; Pío Baroja's posthumous novels; Baroja and the Spanish Civil War. 


\section{INTRODUCCIÓN}

A principios de junio de 1936 Pío Baroja abandonó Madrid para dirigirse a Vera de Bidasoa, dispuesto a pasar el verano en la casa familiar. Unas semanas más tarde, cuando iba con el médico del pueblo a ver el paso de las tropas nacionales procedentes de Pamplona, fue detenido por una partida carlista, acusado de ser enemigo del carlismo y encarcelado (Baroja 1998, 25-33; Caro Baroja 2000, 19-24; Pérez Ferrero 1972, 252-259; Sánchez Ostiz 2000, 147-162). Al día siguiente, tras ser puesto en libertad, salió voluntariamente hacia el exilio en Francia, donde permanecería hasta el 24 de junio de 1940. Una vez en el país vecino, comenzó a recoger testimonios de otros refugiados españoles que iban llegando a Francia huyendo de la guerra, así como noticias aparecidas en la prensa francesa, que seguía de cerca el conflicto bélico español. Esta labor, que complementaría a su regreso a España con nuevos testimonios y anécdotas, serviría de base para recrear en forma novelesca una serie de episodios y acontecimientos relacionados con la Guerra Civil, tema que llegaría a convertirse en una obsesión ${ }^{1}$. Una de estas novelas fue Miserias de la guerra, redactada entre 1949 y 1951, cuando el autor rondaba los ochenta años y padecía insomnio, arterioesclerosis y problemas de memoria (Caro Baroja 2000, 49-56 y 159-161; Granjel 1992, 127-136), lo cual podría explicar algunas repeticiones e inconsistencias en cuanto a fechas y datos históricos (Sánchez Ostiz 2007, 333) 2 .

Uno de los manuscritos existentes fue rechazado por la censura en 1951 por contener comentarios negativos sobre los falangistas, referirse a la barbarie fascista durante la guerra y hacer alusiones a la mediocridad y el fanatismo del pueblo español, de manera que no vio la luz hasta 2006, en que fue publicada por la familia del escritor ${ }^{3}$. La citada obra posee un indudable valor biográfico, testimonial y testamentario, como ya ha señalado Miguel Sánchez-Ostiz (2006,

${ }^{1}$ Además de la trilogía de las Saturnales, Baroja publicó numerosas obras donde se tratan diferentes aspectos de la Guerra Civil, entre ellas las novelas Susana y los cazadores de moscas (1938), Laura, o la soledad sin remedio (1939) y La veladas del chalet gris (1951), donde se recrea el ambiente del Madrid revolucionario y se explora la repercusión de la guerra en la vida de los personajes; libros de memorias, como La guerra civil en la frontera (2005) y Rojos y blancos (2013); y los ensayos que aparecen incluidos en el volumen V de las Obras Completas (1948), así como los recogidos por Miguel Ángel García de Juan en Desde el exilio (1999), Libertad frente a sumisión (2001) y Los inéditos de hoy (2003).

2 Miserias de la guerra es la segunda novela de la trilogía titulada Las Saturnales, iniciada en 1950 con El cantor vagabundo y concluida en 2015 con la publicación póstuma de Los caprichos de la suerte.

${ }^{3}$ Los censores tacharon 247 líneas y subrayaron 533 a lo largo de 48 páginas (Torrealdai 1998, 88-92). Al parecer, Baroja no incorporó ninguna de las tachaduras de la censura a la copia en la que trabajó en 1951 y finalmente acabó por abandonar la novela (Sánchez Ostiz 2000, 187-188; Sánchez Ostiz 2006, 327). Baroja sufrió la persecución de la censura hasta su muerte por ser considerado un escritor contrario al Estado franquista, a la Iglesia 
$325)^{4}$, ya que no solo aclara la postura de Baroja en torno a la Guerra Civil y a su tan traída y llevada ideología política ${ }^{5}$, sino que recoge muchos de los temas que había venido «rumiando» de manera casi obsesiva en los textos redactados en torno al tema de la guerra ${ }^{6}$. Además, como veremos a continua-

católica, y a la familia, y porque su literatura era «disolvente en máximo grado» (Abellán 1980, 17; Sinova 2006, 233-234).

${ }^{4} \mathrm{Si}$ bien Miserias de la guerra entraría en el grupo de novelas barojianas catalogadas por algunos críticos como «obras de vejez» (Nora 1968, 220), de «senectud» o «crepusculares» (Sánchez-Ostiz 2007, 326-349), que esencialmente incluyen todas las escritas después de 1937, ha recibido algunos elogios por parte de la crítica. José Belmonte Serrano considera que el relato muestra que Baroja "seguía estando en forma» a pesar de su edad avanzada $(2006,54)$. Para José Carlos Mainer, esta novela corrobora la preocupación del autor vasco por la responsabilidad moral de los españoles en la contienda, así como la fascinación y el rechazo que siente por la violencia (2012, 365-366). Por último, Miguel Sánchez Ostiz, al referirse a Miserias de la guerra y Los caprichos de la suerte, observa que ambas novelas, «como documentos para saber qué es lo que pensaba o cómo había vivido Baroja los acontecimientos históricos que le habían tocado en suerte, la Guerra Civil en concreto, son insustituibles» $(2007,339)$.

${ }^{5}$ Desde la publicación en 1938 de Comunistas, judíos y demás ralea son numerosos los autores que insisten en considerar a Baroja como un simpatizante del fascismo y del régimen franquista. Así, Eutimio Martín mantiene que el escritor vasco es uno de «los más preciados servidores del franquismo» y lo considera «patriarca indisputado de los azules aprendices de novelistas» $(1975,120,132)$; además, según este crítico, fue muy solicitado para ediciones populares como La novela corta, y revistas dirigidas por falangistas, como Escorial e Índice (1975, 132-133). Frente a la postura de Martín, José A. Gómez Marín observa que los fascistas españoles intentaron «rescatar para sus intereses el prestigio de la Generación del 98», aunque sin éxito; de ahí su interés en Baroja (1974, 38-39). Andrés Trapiello sostiene que «por cada línea antidemócrata de Baroja, pueden citarse veinte demócratas de la cruz a la firma, legales las unas y las otras, coherentes con Baroja todas ellas» $(1994,144)$. Jordi Gracia, por su parte, intenta rescatar la figura de Baroja y otros intelectuales como Azorín, Ortega y Gasset, Gregorio Marañón y Pérez de Ayala que, traicionando sus convicciones liberales, sucumbieron a las promesas de orden de los militares sublevados y acabaron siendo silenciados por el franquismo. El citado investigador mantiene que Baroja, aunque se equivocó al apoyar al bando sublevado, «fue coherente con lo que pensó y escribió antes de la guerra» $(2004,92)$, ya que a su regreso del exilio siguió condenando los dos bandos, denunciando el aparato ideológico de todos los totalitarismos, criticando el carácter dogmático del comunismo y el fascismo, y afirmando su liberalismo frente a la dictadura franquista.

${ }^{6}$ En Ayer y hoy, publicado en Chile en 1939, Baroja mismo reconoce su tendencia a volver sobre los mismos temas: «Parece que el escritor tiene algo de rumiante y que vive más de los recuerdos que en los hechos, porque ahora, en salvo, me tiembla la mano al escribir, como si el recordar el peligro fuera para mí más desagradable que el afrontarlo y tenerlo delante» (Baroja 1998, 33). Entre estos temas y motivos recurrentes que aparecen en las obras sobre la Guerra Civil, destacan los ataques a los «ilustres charlatanes» del Gobierno republicano, el clima de intransigencia y fanatismo que domina en España por esos años, la represión brutal llevada a cabo en la zona roja antes y durante la guerra, su escepticismo en materia política e ideológica, la futilidad de las utopías políticas, las críticas 
ción, Baroja recurre a las convenciones del género apocalíptico para articular una visión de la Guerra Civil que le permita reflexionar - desde la óptica privilegiada de la posguerra - en torno a los acontecimientos de la historia contemporánea que contribuyeron a la polarización ideológica de los españoles, y para profetizar por medio de las visiones del personaje de Hipólito los resultados devastadores de la contienda?

El género apocalíptico, como bien descubrieron varios prelados desde el principio del Alzamiento Nacional, proporciona el marco ideal para contextualizar los eventos políticos y sociales de un momento histórico dado, otorgándoles un valor religioso e incorporándolos a un esquema trascendente de significado. Además, la retórica apocalíptica constituye una estrategia poderosa a la hora de explicar o justificar la violencia asociada con momentos de crisis y recabar apoyo para una determinada causa; de ahí que desde la antigüedad haya sido evocada con fines políticos concretos (Brummett 1991, 87-121; Cunningham y Grell 2000, 1-7; McGinn 1979, 28-36, 246-252). Según Bernard McGinn, en los textos pertenecientes al citado género existen dos acercamientos fundamentales a la hora de interpretar situaciones políticas y sociales críticas: un acercamiento a priori, en el que se utiliza el escenario apocalíptico ya establecido para analizar acontecimientos presentes especialmente conflictivos, apoyar una postura concreta, demonizar al enemigo mediante su identificación con las fuerzas del Mal e incitar a los destinatarios a la acción; y un acercamiento a posteriori, que presenta una visión retrospectiva de los eventos y una reacción a cambios políticos y sociales importantes (1979, 33-35). Como veremos a continuación, esta diferenciación hecha por McGinn resulta sumamente útil a la hora de valorar, por una parte, las perspectivas de los líderes religiosos españoles que apoyaron el Alzamiento y la Guerra Civil desde sus inicios y, por otra, la perspectiva retrospectiva que Baroja ofrece en Miserias de la Guerra.

\section{El aCERCAMIENTO A PRIORI: LOS ARQUitectos DE LA CRUZADA}

El cardenal primado de España Isidro Gomá, en un informe fechado el 13 de agosto de 1936, caracteriza la guerra como un enfrentamiento entre las fuerzas del Mal, representadas por las hordas marxistas, y las fuerzas del Bien, representadas por los insurgentes, incidiendo así en el carácter trascendente de

al sistema parlamentario, etc. Muchas de estas ideas rayan en la manía (Sánchez Ostiz 2007, 12-35, 340-349).

7 Al parecer, Baroja fue lector asiduo de los Evangelios y alude a la Biblia con bastante frecuencia en sus escritos (Pérez Ferrero 1972, 274). Véanse, por ejemplo, las alusiones al Evangelio en Bagatelas de otoño (Baroja 1949, 1329), «Los sistemas totalitarios» (García de Juan 1999, 61-63), y Ayer y hoy (Baroja 1998, 25, 125). 
la lucha. Según él, los enemigos destacan por su «ferocidad inaudita» y su «carácter ultra-impío», y actúan a merced de «una mano diabólica» dirigida contra la Iglesia, mientras que los insurgentes defienden la libertad de España y los ideales religiosos, y se mueven impulsados por el deseo de combatir las leyes laicizantes de la Segunda República y las persecuciones de que son víctima los auténticos españoles, vinculando así su causa con la de los cristianos perseguidos que describe San Juan en el Apocalipsis (Andrés-Gallego y Pazos 2001, 80-89). Se trata, en definitiva, de una «defensa de la civilización cristiana» y de una «guerra santa» en la que luchan la «España y la anti-España, la religión y el ateísmo, la civilización cristiana y la barbarie», y solo el triunfo del movimiento militar puede garantizar la restauración del orden, la paz y la libertad de la Iglesia en la nueva España (Andrés-Gallego y Pazos 2001, 80-89).

De manera semejante, en la Carta pastoral titulada Las dos ciudades, publicada el 30 septiembre de 1936, Enrique Pla y Deniel comienza refiriéndose a «los presagios de tempestad» con que se abrió el año 1936 y el huracán que se desencadenó con posterioridad, evocando de este modo los cataclismos naturales que suelen acompañar los textos apocalípticos. Alude asimismo a las atrocidades perpetradas por «los sin Dios»: destrucción de templos, persecuciones, venganzas, sacrilegios, saqueos, incendios, etc. Si bien Pla y Deniel puntualiza que la Iglesia no se entromete en política, explica la decisión de los prelados españoles de apoyar la rebelión militar diciendo que no se trata de una guerra civil sino una «defensa de la civilización cristiana y de sus fundamentos [. . . ] contra los sin Dios y contra Dios» y «una cruzada por la religión y por la patria y por la civilización» (1936, 30-31). Al igual que ocurre en los textos apocalípticos, las imágenes de destrucción van acompañadas de mensajes de esperanza dirigidos a los destinatarios, asegurando que la hecatombe que se está produciendo en España es parte del plan divino: «es Dios el que con su providencia, a veces inescrutable en sus designios, alza y hunde los imperios y señala el ocaso aun a los genios de la guerra» $(1936,24)$. Por ello, hace un llamamiento a los españoles para que se unan a la sublevación y se sacrifiquen por Dios y por la Patria, y para que sigan floreciendo «las flores rojas del martirio» $(1936,9)$.

Un año después de estallar la guerra, el 1 de julio de 1937, se publica la Carta colectiva de los obispos españoles, redactada por Gomá a instancias de Franco y suscrita por cuarenta y tres obispos y cinco vicarios españoles para defender a la Iglesia de las críticas de que había sido objeto en la prensa católica extranjera y justificar el apoyo a los sublevados. Una vez más, se recurre a la retórica apocalíptica para describir la guerra como un «trastorno profundo» y una «conmoción tremenda [. . .] que sacude los mismos cimientos de la vida social» y que ha puesto en peligro la existencia de España como nación. Además, se concibe el conflicto como un «producto de la pugna de ideologías irreconciliables» en cuyos orígenes se hallan involucradas cuestiones de orden moral, jurídico, religioso e histórico (Andrés-Gallego y Pazos 2004, 331-350). Los obispos firmantes mantie- 
nen que, aunque la Iglesia es «hija del Príncipe de la Paz», algunas guerras son necesarias para lograr la paz, y la del 36 es una de ellas; de ahí que se hayan visto obligados a colaborar con los insurrectos. Un año después de haber estallado la guerra, entonces, se sigue presentando esta como una lucha entre dos tendencias: la espiritual, que defiende el orden, la paz social, la civilización tradicional y la patria; y la materialista, que pretende sustituir la civilización de España por la de los soviets rusos. Se sigue manteniendo asimismo que el triunfo del Movimiento Nacional es la única esperanza para reconquistar la justicia y la paz; de hecho, para el 1 de julio de 1937 todo parece indicar que el triunfo de la Cruzada franquista está garantizado: según los obispos, no solo se ha producido un resurgir del espíritu nacional sino que se ha visto un renacer del culto divino y de la vida cristiana en las regiones reconquistadas, confirmando así que la muerte de los millares de mártires que se sacrificaron por la causa está dando frutos.

Estos prelados, entonces, siguen de cerca el patrón tripartita de caos-juiciosalvación, que según McGinn preside los textos del género apocalíptico $(1979,6)$, para incidir en que la batalla entre las fuerzas del Bien y del Mal ya ha comenzado y que la restauración del orden no tardará; que la vindicación de los que lucharon por España, por la Iglesia y por Dios es inminente; que el sacrificio de los mártires no ha sido en vano; y que Dios está en control de la Historia (Russell 1964, 205-233). La labor de estos apóstoles será crucial a la hora de urdir una narrativa que justifique la rebelión militar y siente las bases retóricas de la Cruzada como defensa de la civilización cristiana y como guerra justa y necesaria. A partir de entonces crecerán las alusiones e interpretaciones religiosas por parte de otros obispos (Chao Rego 2007, 27-28), de los bardos del Alzamiento como José María Pemán, de los simpatizantes de la Cruzada y de muchos otros autores empeñados en justificar la rebelión militar y el carácter religioso del movimiento nacionalista (Payne 1987, 219) ${ }^{8}$. Franco mismo, que según la Proclama del Alzamiento del 17 de julio de 1936 solo pretendía restablecer el orden y la paz, empezará a utilizar esta retórica en sus discursos y a presentar a los rojos como «los enemigos de Dios y de España», a los nacionales caídos como «los mártires de la cruzada», y la guerra como «una defensa de la civilización occidental», «un movimiento salvador», una «Cruzada de Liberación» y una «guerra santa» (DíazPlaja 1976, 11; Redondo 1993, 189, 607-608). Y por si hubiera dudas en cuanto a la esencia religiosa y a la trascendencia de esta guerra, el mismo Papa Pío XII, que al principio se mostró reacio a apoyar el Alzamiento, acabará bendiciendo la Cruzada por medio de un telegrama y un discurso radiado emitido el 16 de abril de 1939 lleno de tópicos apocalípticos, confirmando que, efectivamente, los designios de la Providencia se habían vuelto a manifestar de nuevo sobre España y «la nación elegida por Dios como principal instrumento de la evangelización del

\footnotetext{
8 Véanse, por ejemplo, además del Poema de la Bestia y el Ángel de José María Pemán, los artículos del Marqués de Quintanar, José Pemartín y José M. ${ }^{a}$ Salaverría, publicados en el $A B C$ de Sevilla.
} 
Nuevo Mundo y como baluarte de la fe católica» acababa de demostrar la superioridad de los valores de la religión y del espíritu por encima del ateísmo materialista de los enemigos de Jesucristo (1936, 151-154). De este modo, la consagración papal sanciona las versiones apocalípticas de la Guerra Civil urdidas por los arquitectos del andamiaje franquista, según las cuales la Historia es concebida como una totalidad predeterminada por Dios y como una guerra en defensa de la Iglesia y los valores de la civilización occidental.

No es casual, entonces, que Baroja recurra a esta misma retórica, que para mediados del siglo XX ya los líderes religiosos y la maquinaria propagandística de la dictadura habían conseguido cimentar en la conciencia de los españoles, para elaborar un contradiscurso apocalíptico destinado a socavar los mitos franquistas en torno a la guerra ${ }^{9}$.

\section{El aCerCAMIENTO a POSTERIORI: MiseriaS DE LA GUERRA}

Frente al acercamiento a priori de Gomá y Pla y Deniel, que hacen uso del escenario político y social de 1936 para interpretar la guerra como un momento de crisis suprema, incorporarla a un esquema divino, otorgarle validación

${ }^{9}$ Durante la guerra y la posguerra Baroja continuaría mostrándose sumamente crítico de todas las religiones institucionalizadas y lanzando ataques sutiles a la Iglesia católica española. En «Los frutos de la cultura», publicado el 26 de febrero de 1939 en La Nación, señala que las religiones no han servido para mejorar al hombre. Todas ellas, incluida el cristianismo, han preconizado la bondad y la caridad, y han condenado el asesinato, el robo y el odio al prójimo; sin embargo, «todas ellas dan soldados, sicarios y verdugos, y todas están empapadas de sangre desde la cabeza hasta los pies» (García de Juan 1999, 272-273). Esta idea aparece también en «La moral pública y la individual», donde observa que «la esencia cristiana, evangélica, es tan escasa en el catolicismo o el protestantismo iberos, que se puede decir que es nula» (Baroja 1948, 1008). Puntualiza, además, que uno de los mandamientos de la ley de Dios es no matar; pero, según los religiosos, está permitido matar en tiempo de guerra porque el olor a la pólvora lo desinfecta todo (Baroja 1948, 1008). En «Los enemigos del liberalismo», critica el cariz religioso que ha adquirido la educación universitaria en la nueva España de Franco, y más concretamente el proyecto de crear una universidad «católica y política» de la que no saldrán más que fascistas y comunistas, fanáticos rojos o blancos. Se burla asimismo de los católicos españoles que pretenden unir la religión y la ciencia y que insisten, siguiendo al historiador Marcelino Menéndez y Pelayo, en «que la ciencia española tuvo un éxito al afirmar el dogma de la Purísima Concepción» (Baroja 1948, 993-994). Acusa a las religiones de proclamar, por una parte, la igualdad de todos los hombres y favorecer por otra las diferencias de categoría y de casta; de tener un mandamiento como no matar, y luego asesinar a todos sus enemigos (Baroja 1948, 995). Por último, en «Los sistemas totalitarios» denuncia a la Iglesia Católica no solo de haber defendido una sociedad organizada con reyes, emperadores, jueces, ejército e Inquisición, sino de haber celebrado matanzas como las dragonadas y la Saint Barthélemy, y por no protestar jamás contra «la usura, la explotación del pobre, ni la prostitución» (García de Juan 1999, 62). 
religiosa y apelar a los destinatarios en busca de apoyo para la causa, Baroja opta por ofrecer una visión a posteriori del desarrollo y los resultados catastróficos del conflicto. Aunque a primera vista presenta un aspecto un poco desaliñado, Miserias de la guerra responde, como los textos de Gomá y Pla y Deniel, a la misma estructura tripartita de crisis, juicio y salvación a la que se refiere McGinn. La presentación de la crisis y la reconstrucción del escenario apocalíptico donde tendrá lugar el enfrentamiento entre las fuerzas en conflicto ocupa la mayor parte de la novela y corre a cargo de dos personajes cuyas voces se diluyen a menudo con la del narrador en tercera persona. En primer lugar, Evans, militar y diplomático inglés que trabaja como agregado de la Embajada Inglesa de Madrid y que insiste en su intención de ser un simple espectador de los sucesos que se desarrollan en la capital madrileña, irá recreando en su diario el panorama de la España de preguerra en base a los testimonios de varios personajes, entre los que destaca Juan Goyena y Elorrio, un alter ego de Baroja. En segundo lugar, Will, el chófer de la Embajada, nos pondrá al corriente de la situación madrileña por medio de las cartas que dirige a Evans una vez que este abandona la capital madrileña. El juicio definitivo y la supuesta salvación que sobrevienen al final del proceso apocalíptico son introducidos por Hipólito, un joven de aspecto ingenuo y juvenil que cree ciegamente en la bondad de las ideas anarquistas y la generosidad de los hombres. Mientras espera la ejecución a manos de los nacionales, Hipólito será también el destinatario de una serie de visiones que confirman y anticipan el desenlace catastrófico de la guerra.

En su diario, Evans va describiendo una serie de acontecimientos que, en su opinión, serían decisivos a la hora de preparar el escenario de la tragedia de 1936, convirtiéndose así en portavoz de muchas de las mismas ideas políticas de Baroja que encontramos en los ensayos publicados a partir de $1931^{10}$. El diplomático inglés recrea el estado de anarquía en que

${ }^{10} \mathrm{La}$ actitud de Baroja hacia la República fue siempre sumamente negativa. En un artículo titulado «Una explicación», publicado en Diario de Navarra el 1 de septiembre de 1936 y recogido en $A B C$ el 24 de junio de 1939, al hacer balance de su ideología política, señala que meses antes de la proclamación de la República ya estaba claro que iba a haber un intento de revolución social y de comunismo dirigido en parte por los judíos de Moscú. Baroja criticará en este ensayo el parlamentarismo, por atraer a los arribistas y los ambiciosos, y por fomentar el amiguismo y la corrupción entre los políticos. Incidirá también en la ineptitud de los líderes de la República y en su deseo de «mostrar su arte de histriones», particularmente en el caso de «el león Lerroux y la serpiente Azaña». Por último, concluye diciendo que esta red de engaños generada por la República forma un tumor o absceso y «es de desear que lo saje cuanto antes la espada de un militar» (Baroja 1939b, 23). Estos juicios negativos acerca de la República y sus líderes, así como su deseo de que aparezca en dictador que extirpe de raíz el tumor republicano, serán repetidos hasta la saciedad en los ensayos publicados a partir de 1931. Hay que puntualizar, sin embargo, que, aunque considera que la dictadura puede ser útil como un modo transitorio de gobierno en momen- 
se fue sumiendo España después de la implantación de la Segunda República. Saca a relucir los escándalos y chanchullos que contribuyeron al desprestigio de la Segunda República, entre ellos el del estraperlo, la masacre de Casas Viejas y la Revolución de Asturias. Lanza continuos ataques a los líderes republicanos, particularmente a Azaña y Lerroux, a los que caracteriza como tipos terribles, violentos, crueles y mediocres; como charlatanes que solo quieren «hablar y lucirse en una tribuna» (Baroja 2006, 53); y como individuos oportunistas que, si llegara la hora de huir, lo harían después de haber puesto a buen recaudo su dinero, como en efecto ocurre al final de la obra ${ }^{11}$. Incide también en la debilidad e ineptitud del Gobierno de la República a la hora de contener el caos social mientras las turbas revolucionarias se iban apoderando de las calles y lo acusa de haber permanecido impasible ante la oleada de violencia desatada tras las elecciones de 1933 y de haber permitido que continuaran las huelgas, la ocupación de fincas, los incendios y los atracos. Destaca asimismo la pasividad del Gobierno ante los enfrentamientos entre los socialistas y los falangistas, así como la irresponsabilidad de los líderes políticos, que iban preparando a sus huestes con su retórica inflamada y sus «truculentos discursos» para después arrojarlas a unas sobre otras, contribuyendo así a la polarización de los españoles y a la división en «dos campos enemigos irreductibles e irreconciliables» (Baroja 2006, 88, 93). Por último, subraya la falta de previsión de los líderes republicanos a la hora de frenar la sublevación del Ejército español de África — a pesar de que se sabía desde hacía tiempo que iba a ocurrir algo por el estilo ya que los mismos sublevados se lo habían advertido - y al decidir rendirse al capricho de la masa y armar a la población (Baroja 2006, 119-120).

Frente a Gomá y Pla y Deniel, que establecen desde el principio una división tajante entre buenos y malos, en Miserias hay un esfuerzo deliberado y consistente por borrar esas fronteras e incidir en las semejanzas entre falangistas, socialistas,

tos en que el país se encuentra en peligro, en ningún momento se pronuncia a favor de los totalitarismos, incluido el fascismo. Los ataques a la República y su decisión posterior de no apoyar el bando leal durante la guerra le granjearon la enemistad de los rojos, quienes le consideraron un traidor (García de Juan 2001, 43, 234-235), particularmente después de la aparición en 1939 de Comunistas, judios y demás ralea, donde Giménez Caballero le proclama «precursor del fascismo español» (Baroja 1939a, 3). No obstante, su adhesión al Movimiento Nacional siempre fue cuestionable y, aunque en 1938 publicó algunos artículos en la zona nacional, estos carecían del tono exaltado propio de los escritos adulatorios a Franco y la Cruzada o se limitaban a lanzar ataques generales al marxismo y el judaísmo pasando por alto los elogios al Caudillo y las alusiones al desarrollo de la guerra o a la situación en que se encontraba el país.

${ }_{11}$ Precisamente la obra se cierra con una alusión a «los cucos [que] se escaparon con habilidad y con dinero» mientras que «los torpes, por falta de comprensión, o de astucia, cayeron en la trampa» (Baroja 2006, 318). 
comunistas y anarquistas, así como entre los dos bandos que lucharon en la guerra. Goyena atribuye estas semejanzas al sustrato semítico que se encuentra en la base de la cultura española. Para él, el semitismo no solo «ha sido una de las enfermedades más graves de Europa» sino que ha infiltrado la vida de los pueblos mediterráneos, contaminando todos los aspectos de la sociedad, incluidas la religión y la política, y dando origen a todos los absolutismos (Baroja 2006, 76) ${ }^{12}$. Según Goyena, el sentir de los pueblos semíticos — que aparece resumido en la máxima rencorosa del Evangelio «El que no está conmigo está contra mí»— no solo se encuentra presente en las religiones organizadas y en el sentimiento religioso de los españoles sino, también en la base de la Inquisición, en el espíritu jesuita y en toda la política española, que se reduce a dogmas de derecha y dogmas de izquierda, haciendo que el comunismo y el fascismo sean como «la cara y la cruz de la misma moneda» (Baroja 2006, 87, 79); de ahí que Lenin y Stalin leyeran con frecuencia los Ejercicios espirituales de San Ignacio de Loyola y que los comunistas rusos estudiaran la estrategia de Loyola «como se estudia el manejo de un arma que se intenta emplear» (Baroja 2006, 75). Goyena mantiene que el fermento semítico explica también los paralelismos entre la religión y las ideologías políticas; por ello, describe a Karl Marx como una especie de profeta judío como los de la Biblia y el comunismo como una religión tan irracional y dogmática como las demás. Por último, vincula la esencia judaica con el espíritu rencoroso, la crueldad y la intolerancia del pueblo español, así como con los actos de barbarie llevados a cabo antes y durante la guerra, y augura que, a causa de este fermento judío disolvente que permea todos los aspectos de la cultura, «el odio en España no se acabará nunca» (Baroja 2006, 77) ${ }^{13}$.

Si bien en algunos textos publicados durante el exilio denuncia por igual la barbarie blanca y la roja (Baroja 1998, 91-95, 147-157), en Miserias se

${ }_{12}$ Ya en los artículos publicados en La Nación y en Ayer y hoy, Baroja concibe el falangismo como una tendencia totalitaria comparable al fascismo italiano, al nacionalsindicalismo alemán y al socialismo soviético (García de Juan 1999, 60). Además, equipara a los fascistas con los socialistas y los comunistas, acusándolos de ser igualmente míseros, de utilizar métodos igualmente violentos y de hacer alarde de la misma chulería. En estos textos, el escritor mantiene que todos los movimientos totalitarios tienen sus profetas y sus utopías, y aspiran a implantarse como religiones. De ahí que el marxismo adquiera carácter de cruzada; que los comunistas consideren a Karl Marx como una especie de San Pablo; que los fascistas consideren a Marx como Satanás, el Anticristo, Judas o la Bestia Apocalíptica (Baroja 1998, 125); y que persigan y traten de exterminar el marxismo por todos los medios. Por esa misma razón, para Baroja, la Internacional, la bandera roja y el puño en alto son parte de la ceremonia religiosa comunista, tal y como la campanilla del viático lo es para un católico (Baroja 1998, 91-95).

${ }^{13}$ La idea de que el sustrato judío es el origen del odio y la división entre los españoles se convierte en un motivo recurrente en los textos que tratan de la Guerra Civil. Ver «Las ideas de ayer y de hoy» (Baroja 1948, 903, 938); Ayer y hoy (Baroja 1998, 73-74, 120, 156) y La guerra civil en la frontera (Baroja 2005, 903). 
incide sobre todo en la crueldad de los rojos. Evans alude a las persecuciones de religiosos y a las quemas de conventos, a las ejecuciones de presos en una plaza de toros como si se tratara de un espectáculo, y a las escenas de tortura y las matanzas indiscriminadas de prisioneros políticos ocurridas en la Cárcel Modelo, que horrorizaron hasta al propio embajador de los soviets en Madrid. Describe asimismo el mundo tenebroso de las checas comunistas y anarquistas, así como las atrocidades llevadas a cabo por los grupos de represión al servicio de la República, como los Linces de la República y la Escuadrilla del Amanecer, que se dedicaban a robar, matar y perseguir a sus enemigos para exterminarlos. Los ejemplos de barbarie roja, en fin, se multiplican a lo largo de la novela, lo cual es comprensible si se considera que la aprobación del manuscrito dependía de las reacciones favorables de los censores franquistas.

Al resumir la cadena de sucesos acontecidos a raíz del triunfo del Frente Popular en las elecciones, Evans subraya el ambiente amenazante y el aspecto sombrío que ofrecía Madrid en la noche de las elecciones de 1936 $\mathrm{y}$ añade que era «como si se estuviese incubando una tragedia» (Baroja 2006, 113). Alude también a las noticias inquietantes que iban llegando de provincias, la declaración del estado de guerra en toda España, la huida del presidente del Consejo de su puesto, la aparición de un manifiesto de la CNT y la FAI exigiendo la liberación de sus presos y pidiendo la abolición de la ley de Orden Público, y el lanzamiento de las masas a la calle para apoderarse del poder. A esto seguirían las noticias del desbordamiento en todo el país, el amotinamiento de presos en varios puntos de España, la huida de los ricos en sus autos, los asesinatos de José Castillo y José Calvo Sotelo y, finalmente, la sublevación del Ejército español de África (Baroja 2006, 119).

Por último, Evans pone de relieve la alegría y el optimismo reinante entre los madrileños durante los primeros días de la guerra, con las terrazas de los cafés llenas de gente, los vecinos asomados a los balcones de sus casas presenciando las operaciones militares, los soldados y las criadas paseando por las calles de Madrid como en día de fiesta, y la euforia de los primeros triunfos, ajenos por completo al hecho de que la guerra civil había comenzado. Poco a poco, sin embargo, la anarquía y el caos irán viciando el ambiente de fiesta hasta transformarlo en atmósfera de carnaval y pronto los madrileños aparecerán envueltos en una danza de la muerte desenfrenada. Conforme el fanatismo y la locura colectiva se apoderan de la población, el país se va entregando al «sadismo más bestial» (Baroja 2006, 196), el miedo va calando en la población y la ciudad va adquiriendo un cariz siniestro.

En octubre de 1938, cuando Evans abandona Madrid para irse a Valencia, Will resumirá las últimas etapas de la guerra, dedicando varias páginas a relatar su visita la Cárcel de Porlier, la cual servirá de pretexto para exponer nuevos casos de barbarie roja. La mayor parte de su relato, sin embargo, gira 
en torno a la figura de Hipólito, cuyo desencanto con el anarquismo se va haciendo cada vez más patente, especialmente después de ver como León Carnicer no solo ocupa las casas de los ricos y comete todo tipo de atropellos, sino que traiciona a sus propios compañeros. Más concretamente, en los capítulos VII a X del epílogo, Will describe una serie de sueños o visiones que tiene Hipólito en la cárcel mientras espera su ejecución a manos de los nacionales que ofrecen un marcado carácter apocalíptico y elevan la guerra a un nivel alegórico.

\section{Las Visiones de Hipólito}

En el Capítulo VII del epílogo, Hipólito, alucinando entre sueños, experimentará varias visiones:

En el fondo del horizonte cree ver una gran ciudad, llena de torres y palacios, de jardines y de estatuas de mármol. Una luz de eclipse la ilumina.

Hipólito mira los templos con sus altares, en donde sube el incienso en honor de los dioses, los salones regios, las escuelas, los hospitales, laboratorios, en donde trabaja un sabio, las casas míseras con sus gentes, aquí muere un niño y allí nace otro, allá un viejo mendigo se desmaya de hambre y en una taberna de los alrededores es asesinado un joven (Baroja 2006, 310).

De repente, la ciudad se cubre de una gran nube carmesí de aspecto amenazador que representa «una gran bestia bermeja, pesada y sangrienta» semejante a la que aparece en el Apocalipsis de San Juan (Rev 13,1-10). Esta bestia aterroriza a la población con sus numerosas cabezas y tentáculos, aplasta la ciudad, oprime a los hombres, les sorbe la sangre y les cruje los huesos (Baroja 2006, 310). A continuación, se presentará en el cielo una mujer alta y fuerte vestida de rojo, que evoca a la ramera vestida de escarlata de la Biblia (Rev 17,1-5), tocando una trompeta y congregando una muchedumbre que va formando batallones para, acto seguido, dar comienzo a una terrible lucha en la ciudad y en los campos que hace correr la sangre a torrentes por todas partes. Los cañones disparan desde los montes y los valles, y las casas y los templos se derrumban, quedando en pie solo columnas rotas y pedazos de estatuas. Hipólito oye el lamento de una madre que aparece con su hijo muerto en brazos y el de un hijo que tropieza con el cadáver de su padre, que ha sido destrozado por la metralla, así como las blasfemias y los lamentos de los moribundos. Finalmente, tras concluir la lucha, sobreviene una gran putrefacción en la tierra y la muerte se apodera del universo, dejando a los hombres, los animales y hasta las máquinas inmovilizados, mientras las cenizas invaden las ruinas. Con todo, la escena se cierra con «una vaga claridad de sol» y con señales de regeneración en la forma de rumores, voces infantiles y campos que 
reverdecen (Baroja 2006, 311). Esta visión se complementa en el próximo capítulo, que se abre con una visión de un campo de batalla moderno y con Hipólito caminando «solo, triste y desfallecido de hambre por una tierra árida», bajo un cielo «nublado y sin estrellas» y un «aire pesado y tempestuoso» $(\mathrm{Ba}-$ roja 2006, 312). De pronto, ve una serie de relámpagos que anuncian una gran tormenta, truenos espantosos, estrellas que comienzan a girar de un lado para otro con furia y cometas que surcan el cielo con sus colas luminosas. Tras contemplar estos cataclismos, el cielo «se aclara con una luz de crepúsculo o una aurora boreal» (Baroja 2006, 312). Al igual que en el texto de San Juan, ambas visiones de Hipólito van acompañadas de una «voz estridente» exhortándole a mirar y contar a los hombres lo que ve, «porque nadie en el mundo ha presenciado algo parecido» (Baroja 2006, 310-311).

Las dos primeras visiones de Hipólito, entonces, evocan la estructura del texto bíblico de San Juan, al presentar escenas de la devastación causada por las serie de catástrofes naturales y humanas que supuestamente asolarán la tierra $^{14}$, desde las lanzadas por los cuatro jinetes que son enviados por Dios para llevar hambre, guerra y muerte a la humanidad (Rev 6,1-8), hasta las que son resultado de desastres naturales y sobrenaturales que sobrevienen al abrise el séptimo sello (Rev 8,1-13) o al derramarse las copas de la ira divina sobre la tierra (Rev 16,1-21). No obstante, a pesar de la violencia de las imágenes contempladas por Hipólito, ambas visiones contienen señales de regeneración y concluyen con un pronóstico optimista del futuro, al completarse el ciclo de crisis, destrucción y regeneración característico de los textos apocalípticos. Estos augurios evocan la esperanza que subyace en los textos bíblicos, donde las señales que anuncian el fin del mundo van seguidas de otras que predicen la derrota definitiva de las fuerzas del Mal, la celebración de Juicio Final, la transformación de los cielos y la tierra, la aparición de la Nueva Jerusalén y la comunión gozosa con Dios. Todo indica, entonces, que, aunque el mundo parece caminar hacia la destrucción, Dios no permanece impasible ante el dolor de los cristianos perseguidos ni tampoco está al margen de los acontecimientos

${ }^{14}$ De manera semejante, en el Evangelio según San Mateo, al referirse a las grandes calamidades que precederán la segunda venida del Mesías, el autor asegura que «no quedará piedra sobre piedra, pues todo será derribado» (Mt 24,1-2); enumera una serie de fenómenos que anuncian el fin -guerras, pestes, hambres, terremotos, persecuciones, odio, aparición de falsos Cristos y falsos profetas-; anticipa la venida de Jesucristo; y, por último, describe las señales que anunciarán tal acontecimiento (Mt 24,29-31). Según San Mateo, durante este juicio, que tendrá lugar tras la segunda venida de Cristo, los seres humanos serán juzgados según sus obras y se decidirá su destino final; por ello, exhorta a las comunidades judeocristianas a prepararse para ese momento. San Lucas, por su parte, al describir las señales que precederán la llegada del Hijo del Hombre, afirma que «se levantará nación contra nación, y reino contra reino, y habrá grandes terremotos, hambre, pestilencias, terror y grandes señales del cielo» (Lc 21,10-11). 
históricos sino que continúa dirigiendo la Historia y encaminando a la humanidad hacia la llegada de los nuevos tiempos.

Las esperanzas de renovación presentes en las dos primeras visiones, sin embargo, desaparecerán en el siguiente capítulo, donde se presenta una escena que evoca El triunfo de la Muerte de Bruegel:

El paisaje desolado, con sus colinas áridas, y en el fondo el mar con barcos que naufragan; en las colinas amarillentas hay un árbol roto, y una horca en la que cuelga un cadáver, y un esqueleto que decapita a un hombre. En primer término, campos llenos de cadáveres, guerreros que se matan, carros con fantasmas blancos, la mujer llevada en triunfo desnuda, y el esqueleto con la guadaña y con un reloj de arena en la mano (Baroja 2006, 313).

Esta escena inspirada en el Apocalipsis de San Juan (Rev 6,8-15; 8,7-9; $9,16 ; 19,17-18)$, ofrece una visión de un mundo en crisis dominado por ejércitos de esqueletos guerreros que se enzarzan en una persecución encarnizada de los vivos para exterminarlos indiscriminadamente, sin atender a su condición social, su género, su edad, o sus buenas obras en vida, mientras tratan de huir aterrorizados o de luchar en vano. En la parte inferior derecha, un esqueleto armado de una guadaña y montado en un caballo esquelético va juntando a un grupo de vivos como si fueran ganado y guiándolos hacia su destino final: una puerta estrecha semejante a la que San Mateo menciona en su Evangelio (7,13-14). El resto del cuadro aparece ocupado por esqueletos que persiguen con saña a los vivos, los atrapan con redes y los someten a todo tipo de torturas y métodos de ejecución, como la horca, la picota y las ruedas para despedazar víctimas. Encontramos también muertes por ahogamiento y por atropello, y otras llevadas a cabo por medio de hachas, guadañas, puñales, etc. Como observan varios estudiosos de la pintura de Bruegel, la obra presenta un inventario de todas las formas posibles de muerte, así como un muestrario de las diferentes dimensiones de la crueldad humana (Bonn 2006, 7; Reed 2012, 235-237; Robert-Jones 1997, 98). Cabe señalar que toda esta masacre transcurre en medio de un ambiente festivo -con esqueletos tocando todo tipo de instrumentos musicales, haciendo cabriolas, burlándose de los moribundos o asustando indefensas damas- reminiscente del de la Danza de la Muerte medieval (Infantes 1997, 21-22) y también del ambiente que, según Evans, reinaba en Madrid durante los primeros días de la guerra.

A primera vista, la abundancia de cruces en la obra parece reforzar la existencia de un mensaje religioso: a la izquierda encontramos un grupo de esqueletos ataviados con togas tocando trompetas solemnemente detrás de una gran cruz roja y presidiendo la masacre; a la derecha, otros esqueletos se preparan para el ataque armados de tapas de ataúdes adornadas con una cruz que utilizan a modo de escudo; se observa también que la puerta por donde van pasando los condenados tiene otra gran cruz roja pintada. No 
obstante, la cruz no parece proteger a los cristianos; más bien, sirve de estandarte a los ejércitos de esqueletos que llevan a cabo un esfuerzo sistemático y organizado por exterminar a los vivos, sin que les valgan de nada las promesas de salvación anunciadas por los textos bíblicos o las esperanzas que pudieran tener de misericordia divina. Los esqueletos, y no Jesucristo, son los que determinan el destino de los vivos $\mathrm{y}$, al parecer, no discriminan entre los que tienen el sello de Dios en la frente ( $\operatorname{Rev} 7,3-4)$ y los condenados. La referencia a las escenas del fin del mundo representadas en El triunfo de la Muerte, entonces, desvirtúa por completo las promesas de regeneración de las dos primeras visiones de Hipólito y subvierte los mensajes convencionales del cristianismo referidos a la vida eterna y a las utopías judeocristianas. Como observa Walter Gibson, en El triunfo de la Muerte no encontramos ni juez, ni juicio, ni vindicación de los justos, ni esperanzas de resurrección; se trata de una guerra de exterminio en la que nadie se salva $(1991,59)$. Este sentido de finalidad de la muerte aparecerá reforzado en la siguiente visión, inspirada en Los cuatro jinetes del Apocalipsis de Alberto Durero, donde Hipólito aparece cabalgando entre montañas de muertos como un caballero de Durero; a su alrededor solo ve incendios, «un gran osario lleno de calaveras», «un carro con esqueletos que tocan trompetas», y esqueletos que se llevan a las monjas y a los niños al son de flautas y tambores (Baroja 2006, 313-314), evocando así de nuevo la Danza de la Muerte y reafirmando el mensaje pesimista de Bruegel.

Las referencias a las obras de Bruegel y Durero van seguidas por los pensamientos de algunos filósofos que acuden a la mente de Hipólito mientras espera su ejecución: Marco Aurelio le recuerda que «la muerte no es más que un cambio» y no representa algo terrible; Cicerón le dice que «filosofar es aprender a morir» y Séneca que «la muerte es una ley, no un castigo»; Kant, por su parte, comenta que «la naturaleza del hombre no es para encontrar la calma y la paz en la posesión y en el placer» y Schopenhauer observa que «la muerte es la solución dolorosa del mundo formado por la generación con voluptuosidad, en la destrucción violenta del error fundamental de nuestro ser, el gran desengaño» (Baroja 2006, 314). Marco Aurelio, Cicerón y Séneca, entonces, se presentan en la visión de Hipólito para introducir la idea de la vida como un constante viaje hacia la muerte, y esta, a su vez, como parte del orden natural; por ello, recomiendan resignación y sugieren que el ser humano debe vivir la vida preparándose para la muerte y recibirla con serenidad, sin esperar intervención divina. Los tres inciden en la importancia de la filosofía en la vida del hombre y establecen ciertas normas que deben regir su conducta individual, como la práctica de la virtud, el ejercicio de la razón y el amor al prójimo. Por otra parte, las referencias al pensamiento de Kant y Schopenhauer tienen que ver con la imposibilidad del ser humano de alcanzar un estado de felicidad. En la Crítica del Juicio Kant mantiene que no está en la naturaleza del hombre el ser 
feliz; el ser humano no solo no llega a estar satisfecho nunca con lo que tiene sino que se empeña en procurar la destrucción de su propia especie a través de las guerras (1987, 317-321). Por último, Schopenhauer, al igual que Marco Aurelio, Cicerón y Séneca, concibe la muerte como una parte de la vida del hombre y como una liberación, aunque no del sufrimiento, sino de la conciencia individual; de hecho, según el citado filósofo, la mayoría de los hombres no podrían ser felices nunca, con lo cual no parece existir posibilidad alguna de felicidad para el ser humano. Vemos, entonces, que las preocupaciones metafísicas en torno a la conducta individual y el pesimismo schopenhauariano presentes en los primeros escritos de Baroja afloran de nuevo en los sueños de Hipólito, y que Baroja sigue rechazando el dogma de la Iglesia y la moralidad cristiana hasta el final de su vida, responsabilizando al ser humano de su conducta.

El tema de la salvación reaparecerá en la última visión de Hipólito, donde sueña que va montado en un caballo blanco y se encuentra con la hueste a la que alude Berceo en «El Milagro de Teófilo», donde este, llevado por su ambición desmedida, vende su alma al diablo por mediación de un judío. Es entonces cuando el Demonio, caracterizado como un rey feudal, aparece con todo su séquito de vasallos y admiradores y da comienzo una batalla alegórica entre las fuerzas del Bien y el Mal, tras la cual tendrá lugar la contrición y la salvación de su alma por medio de la intercesión de la Virgen. Teófilo reconoce su transgresión y, sin renunciar a su fe en María, logra salvarse. Los paralelos entre Teófilo e Hipólito son evidentes: los dos comienzan siendo hombres virtuosos, los dos son víctimas de las malas artes del demonio -encarnadas en el primer caso por un judío y en el segundo por los apóstoles del anarquismo y los líderes de la FAI- y los dos van camino de condenarse. Además, al igual que Teófilo cuenta con la intercesión de la Virgen, Hipólito tiene la posibilidad de salvarse por medio de Blanca Salvat, quien cuenta con amigos influyentes en el bando nacional. No obstante, al encontrarse completamente desilusionado con los ideales anarquistas y con la vida en general, rechaza la ayuda y, con ello, toda posibilidad de salvación. Para Hipólito, que es un hombre esencialmente religioso, el cambio social estaba profetizado en Ezequiel, cuando Gog se lanza sobre los montes desolados de Israel seguido de todos sus guerreros, y en el texto de San Juan, cuando Satanás induce a las naciones del mundo a que se preparen para tomar parte en la gran batalla. Sin embargo, tras ser testigo de tanta crueldad y egoísmo por parte de sus correligionarios, llega a la conclusión de que este no es el cambio que él esperaba y no solo abandona la lucha sino que pierde las ganas de vivir al descubrir que sus ideales altruistas son incompatibles con la España circundante y con la descomposición moral de la época. De ahí que, cuando un capitán del bando nacional le presente la posibilidad de salvarse, Hipólito conteste lo siguiente: 
Prefiero la muerte. He vivido con una ilusión de fraternidad de todos los hombres. Ahora, después de esta guerra, veo que mi idea es una locura. Vivir sin esperanzas, ¿para qué? [. . .] no siento entusiasmo por la vida, que me parece una pobre miseria, y además porque teniendo que obedecer a ustedes viviría muy mal. Así que prefiero la muerte (Baroja 2006, 315-316).

Como muchos héroes barojianos de estirpe schopenhauriana, entonces, Hipólito empezará proyectándose como un personaje que actúa impulsado por sus ideales altruistas para acabar asqueado por el ambiente inmoral que le rodea, consumido por su propia impotencia y pesimismo, y abandonándose a su propia destrucción (Barja 1964, 306-307; Elizalde 1990, 53-54).

Poco antes de su ejecución a manos de los nacionales, Hipólito saca el Evangelio de San Mateo del bolsillo, lo abre al azar y lee dos pasajes. El primer pasaje -«Entrad por la puerta estrecha, porque ancha es la puerta, espacioso es el camino que lleva a la perdición y hay muchos que entran por ella» (Baroja 2006, 317) - se presenta en el Evangelio después de que San Mateo habla de la importancia de no juzgar a los demás para no ser juzgados (Mt 7,13-14). Según se prepara para morir, Hipólito reflexiona sobre estas palabras de San Mateo y sobre su propia conducta y llega a la siguiente conclusión:

Para mí entrar por la puerta estrecha [. . . ] ha sido vivir con dignidad y con libertad. Yo ya sabía muy bien que el entrar por la puerta estrecha era vivir pobremente, no tener protección ninguna, fracasar en muchas cosas, pero a pesar de todo esto, he preferido la estrechez que la anchura con gente pedantesca y cruel, y de una vanidad necia (Baroja 2006, 317).

El segundo pasaje - «Todo árbol bueno, lleva buenos frutos y el árbol malo lleva malos frutos. El árbol bueno no puede llevar malos frutos ni el árbol malo no puede llevar buenos frutos. Así pues, por los frutos los conoceréis» (Baroja 2006, 317)- aparece en el texto de San Mateo después de que este advierte a los cristianos de no dejarse engañar por los falsos profetas y les recuerda que los seres humanos serán juzgados por sus obras (Mt 7,17-19), incidiendo así, como los filósofos citados, en la importancia de que sean consecuentes con sus acciones.

Las visiones proféticas de Hipólito, entonces, exploran los efectos de la Guerra Civil, pero también diferentes perspectivas ante la vida y la muerte. En primer lugar, recrean algunas imágenes de destrucción, terror, violencia, catástrofes cósmicas y pánico que remiten al lector al Apocalipsis de San Juan, donde, al mismo tiempo que se pronostica la destrucción del mundo y se lanzan una serie de advertencias exhortando a los cristianos a arrepentirse y prepararse para el Juicio Final, se anticipa la creación de un mundo perfecto, generando en los destinatarios ciertas expectativas de justicia, salvación y renovación. A diferencia de los textos apocalípticos, las señales de regeneración de las visiones de Hipólito no pasan de ser un amago, cuestionando así la prometida 
salvación de los elegidos, la intervención divina en la Historia, la regeneración que supuestamente sucede a la destrucción y, en general, las expectativas asociadas con el Juicio Final y la vida después de la muerte (Russell 1964, 353385). La alusión al cuadro de Bruegel, por otra parte, niega las utopías religiosas de resurrección y transformación cósmica, refuerza la idea de la inevitabilidad de la muerte y sugiere que no hay salvación posible, ni para los españoles que defendieron sus ideales en el campo de batalla ni para el ser humano en general. Por último, frente a la moral y la concepción providencialista cristiana y a las fantasías religiosas y promesas bíblicas del Paraíso que forman parte del pensamiento religioso tradicional, las alusiones a Marco Aurelio, Séneca, Cicerón, Kant y Schopenhauer reafirman el vacío existente después de la muerte e inciden en la conducta moral y consecuente del individuo en vida.

\section{El CONTRADISCURSO BAROJIANO}

Tanto los textos de Gomá y Pla y Deniel como Miserias de la Guerra recomponen un escenario apocalíptico dominado por persecuciones, incendios y actos de violencia llevados a cabo por unas masas desesperadas que se entregan a la barbarie y siembran el pánico entre la población. Se trata, como observa en Ayer y hoy, de una guerra de exterminio en la que «alienta el odio más puro, porque no solo se quiere vencer, sino castigar al enemigo» (Baroja 1998, 151). Al igual que Pla y Deniel y Gomá, el escritor vasco parece concebir la crisis como una guerra religiosa, como evidencian los incendios de iglesias, la quema de imágenes, la persecución y matanza de religiosos o el desenterramiento de cadáveres de monjas. Además, tanto los prelados citados como Baroja anhelan la vuelta al orden, por lo cual comparten el deseo de que aparezca un mesías o domador capaz de aplacar estas «bestias feroces» con el filo de la espada (Baroja 2006, 39).

No obstante, las diferencias entre los textos de Pla y Deniel y Gomá y Miserias son considerables. En primer lugar, mientras los apóstoles de la Cruzada de 1936 hacen una división tajante entre las fuerzas del Bien y del Mal, Baroja prescinde de tal división para insistir en las semejanzas existentes entre los actores que intervienen en la tragedia española. A lo largo de la novela se incide en que tanto los grupos políticos que pueblan el escenario español como los dos bandos que intervienen en la Guerra Civil son igualmente intolerantes y despóticos, utilizan los mismos procedimientos violentos, muestran las mismas crueldades y barbarie y, en fin, «matan lo mismo unos que los otros» (Baroja 2006, 52). Segundo, mientras los prelados se apoyan en una concepción determinista de la Historia - como suele ocurrir en el género apocalíptico (McGinn 1979, 7-8; Russell 1964, 230-234)_ para presentar una situación desconcertante como parte de los designios de la Providencia, Baroja rechaza 
la intervención divina en los asuntos del mundo y opta por responsabilizar a los líderes políticos republicanos de generar la crisis y conducir a España al abismo, y al pueblo español de subirse al carro de la revolución y dejarse arrastrar por las utopías, el odio, la crueldad y la intolerancia. Tercero, frente a la visión esperanzadora y las promesas de paz, gloria y justicia de los prelados — que es propia del género apocalíptico (Collins 2016, 3-9; Collins 1979, 11; Russell 1964, 104-118) — el escritor vasco mantiene que la guerra solo genera muerte y destrucción, de manera que las promesas a las que aluden Gomá y Pla y Deniel no pasan de ser una estrategia retórica para justificar el apoyo de la Iglesia al Alzamiento y reclutar mártires para la causa nacional. Las visiones de Hipólito parecen sugerir que los españoles están condenados a vivir sumidos en un ciclo de violencia y odio eterno que, como observa Evans, «persiste y estallará otra vez, un día cualquiera, sin saber cuándo ni cómo, dando la sensación de que no se acabará nunca» (Baroja 2006, 307); por esta misma razón, nunca podrán vivir en un régimen de libertad, teniendo que conformarse con «un liberalismo simulado o con una dictadura de república hispanoamericana» (Baroja 2006, 17). Por último, mientras que para Gomá y Pla y Deniel morir en defensa de la religión y la patria es algo trascendente y deseable - ya que los mártires interceden ante Dios por la salvación de España-, para Baroja morir por la causa -sea esta religiosa o política- es una acción futil, dado que todas las utopías son puras fantasías. Al igual que en algunos textos publicados en el exilio, como «Los sistemas totalitarios» (García de Juan 1999, 59-70), «Los frutos de la cultura» (García de Juan 1999, 263 274) o Ayer y hoy, en Miserias se destacan las incongruencias existentes entre las utopías comunistas, que prometían la desaparición de la propiedad privada y la diferencia de clases, y el fenómeno de los «comunistas de automóvil y medias de seda que últimamente florecían en los jardines de la aristocracia española» buscando la forma de medrar, exactamente igual que sus enemigos (Baroja 2006, 141). Se critican también los mensajes de los anarquistas y los milicianos de la UGT, que andaban pregonando el amor al prójimo y «soñando idilios» para luego dedicarse al robo y al asesinato (Baroja 2006, 149). Finalmente, se ponen de relieve asimismo las falsas promesas de justicia y de fraternidad de la República, especialmente en vistas de que los españoles se estaban matando unos a otros, y se incide en lo absurdo de pensar que se puede conquistar la felicidad por medio de una revolución tan sangrienta que va dejando un «camino sembrado de cadáveres» (Baroja 2006, 235).

\section{CONCLUSIONES}

Como acabamos de ver, el concepto de apocalipsis constituye el principio organizador y el centro figurativo de Miserias de la guerra. Al igual que San Juan descifra una serie de señales y se esfuerza por crear una versión coheren- 
te de la crisis que sintetice y abarque el sentido total de la Historia, Baroja, desde la posición privilegiada de la posguerra, echa una última mirada a los sucesos que contribuyeron a la tragedia de 1936 y articula una narrativa en la que la proclamación de la Segunda República representa la aceleración del proceso gradual de desintegración política y social de España, y la guerra una catástrofe de proporciones apocalípticas. No obstante, mientras en los textos apocalípticos la catástrofe va seguida de un período de regeneración, orden y felicidad, en Miserias no se prevé más que muerte, miseria y esterilidad.

En efecto, como corroboran algunos ensayos publicados a su regreso del exilio, unos años después de la guerra el país sigue sumido en la oscuridad y en la más tremenda desolación. Evidentemente, la dictadura militar, que Baroja y otros maestros liberales exiliados como Azorín, Ortega y Gasset, Pérez de Ayala y Marañón consideraban como la única salida posible a la situación crítica en la que se encontraba España, resultaría ser el inicio de una etapa de represión sin precedentes (Gracia 2004, 34, 46-115). Estos viejos liberales, que esperaban ansiosos el momento de regresar a España porque les faltaba «el aire, el paisaje, la familia, el habla, la discusión, es decir, la patria» (García de Juan 2001, 184, 190-191), y que parecían convencidos de que una dictadura militar restauraría el orden en España y protegería su libertad de pensamiento frente a la dictadura de las masas (Baroja 1998, 13, 64, 157), se encontrarán a su regreso con un Estado fascista incipiente que, además, tenía un fuerte componente clerical ${ }^{15}$. El anhelado espadón providencial que supuestamente iba a domar a las «bestias feroces» (Baroja 1998, 39) y que iba a sajar de raíz el tumor o absceso (Baroja 1939b, 23) acabará instalándose en el poder permanentemente, exigiendo una «obediencia estúpida y ciega» (Baroja 1948, 993), suprimiendo el ambiente de libertad y tolerancia, impidiendo al individuo vivir con dignidad y reduciéndolo a «un animal domesticado por un domador tiránico» (Baroja $1948,1124)^{16}$. La actitud hacia los escritores e intelectuales, que durante la

15 Recordemos que en Ayer y hoy Baroja se muestra a favor de una dictadura que no fuera clerical: «una dictadura blanca no siendo clerical es, hoy por hoy, preferible para España. Una dictadura de militares se puede suponer lo que va a ser, consignas más o menos severas, pero con sentido» $(1998,138)$.

${ }^{16}$ La decepción de Baroja con la dictadura franquista es patente en algunos de los ensayos publicados en La Nación. Así, si en «Los herederos de Hegel», publicado el 17 de noviembre de 1939, se refiere a «los dogmas totalitarios de las tres dictaduras europeas» — es decir, el marxismo ruso, el nazismo alemán y el fascismo italiano (García de Juan 1999, 289) — en «Los sistemas totalitarios», publicado en este mismo periódico el 10 de marzo de 1940, incluye el nacionalismo católico de España entre las tendencias totalitarias del momento. Según él, el falangismo, junto con el fascismo italiano, el nacionalsocialismo alemán y el socialismo soviético, tiene un carácter "sindical, social y totalitario» (García de Juan 1999, 60) y, aunque se alza en defensa de la civilización occidental y el cristianismo, no tiene nada que ver con las máximas del Evangelio. De manera semejante, en «El final de una sociedad aristocrática», publicado el 24 de junio de 1940, el escritor añora el aire aris- 
monarquía era de indiferencia y durante la República de antipatía, se tornará con los comunistas y fascistas en «franca hostilidad» (García de Juan 2001, 233-241; 2003, 133-140), de manera que todos aquellos que, como Baroja, no se adapten a las expectativas del régimen y no adopten la retórica altisonante de los vencedores seguirán siendo sospechosos. Por otra parte, el pensamiento liberal, que Baroja, Ortega y otros intelectuales pretendían proteger del totalitarismo comunista al aliarse con el bando sublevado durante la guerra, será suprimido por la dictadura fascista y se verá reducido ahora a gestos discretos para «no levantar suspicacias ni llamar mucho la atención» y a tentativas modestas de proteger «el lenguaje de la razón» frente a la retórica ideologizada y altisonante del fascismo (Gracia 2004, 19, 25). El proyecto de reconstrucción de España ha comenzado, pero bajo la tutela del nuevo Estado totalitario y de la Iglesia, que sigue estando infiltrada en todos los aspectos de la vida española, incluida la educación universitaria y la ciencia (Baroja 1948, 993-994). La división ideológica entre rojos y blancos y el fanatismo que habían contribuido a la polarización de los españoles no solo no han desaparecido al terminar la guerra sino que se han intensificado, de manera que todavía existe «un agujero» (García de Juan 1999, 92), «un abismo que es imposible de llenar» (Baroja 1948, 995-996). La prohibición de obras maestras como La Celestina, las absurdas campañas de moralidad y virtuosismo, la censura de la prensa, la «retórica manoseada» y la propaganda política del nuevo régimen han sumido la cultura española en «uno de sus momentos de eclipse más profundos» del que será difícil recuperarse (García de Juan 1999, 127-131). España, en fin, se ha convertido en «un desierto», un «Sahara sin oasis», «un Mar Muerto del espíritu» porque, como observa Baroja, «el totalitarismo es el viento del desierto que seca, consume y mata, sobre todo lo que sea espiritual» (García de Juan 1999, 130-31).

El panorama de la posguerra, entonces, corrobora que la Guerra Civil ha tenido efectos completamente nulos y que las revoluciones modernas «no dejan nada más que montones de muertos» (Baroja 2006, 92). Lo único que se ha demostrado con esta guerra es que España es «un pueblo de locos y de perturbados» que unas veces se dedica a perseguir eclesiásticos y a quemar iglesias

tocrático del Madrid de finales del siglo XIX, cuando la capital aparecía animada por un «pueblo sonriente» y despreocupado, y cuando la vida era «sonriente y alegre» (García de Juan 1999, 91-92). Seguirá culpando a los «aventureros de la política sin escrúpulos, estilo Lerroux, y la gente de su cuerda» y a los «pedantes del Ateneo del tipo Azaña y compañía» de haber convertido a «la señora que tenía aire y costumbres distinguidos [. . .] en una patrona de casa de huéspedes» $\mathrm{y}$, a los que han venido después, de haber hecho de ella «una sargenta o a lo más una tenienta» (García de Juan 1999, 92). Además, frente a los escritores y periodistas que defienden "el régimen totalitario y despótico», ya sea por miedo, por humildad o por creer que colaboran con los directores, Baroja continuará defendiendo la inclinación liberal de cualquier escritor que se precie de tener «cierta personalidad» (García de Juan 1999, 92). 
e imágenes de madera para cuatro años después hacer cola para rezarle al Cristo de Medinaceli (Baroja 2006, 59, 61); de ahí que, como señala Evans, «querer hacer apología de una revolución así con un ideario tan pobre y tan poco original y con una cantidad de muertes sobre todo asesinatos tan grande, es una estupidez completa» (Baroja 2006, 232). Evidentemente, las utopías religiosas y políticas no han servido para mejorar a los españoles sino para hacerlos tan agresivos y sanguinarios como en la Edad de Piedra y, en última instancia, para conducirlos a su propio exterminio. Por una parte, las religiones preconizan la bondad y la caridad y condenan el asesinato, el robo y el odio al prójimo, pero, como observa en «Los frutos de la cultura», todas ellas están «empapadas de sangre desde la cabeza hasta los pies» (García de Juan 1999, 272-273). Por otra, las teorías laicas como el comunismo, el socialismo, el anarquismo y el fascismo solo piensan en la felicidad del pueblo y en lograr la igualdad y la justicia social, pero tan pronto como estas doctrinas llegan al pueblo y se intentan poner en práctica, «empieza a correr la sangre y no hay más que muertes, incendios y horrores» (García de Juan 1999, 273).

Como se desprende de la lectura de Miserias de la guerra, unos años antes de morir, la postura de Baroja en torno a la Guerra Civil continúa siendo inequívoca: no está ni con unos ni con otros. Al igual que en muchos de los ensayos publicados en La Nación en los años cuarenta, el escritor sigue mostrando su oposición a los totalitarismos, manteniendo que tanto comunistas como fascistas son enemigos de la libertad, y comparando ambos grupos con instituciones religiosas, sus doctrinas con puras fantasías y a sus adeptos con católicos fanáticos y dogmáticos. Además, somete a los que él considera responsables de la catástrofe a una especie de «juicio final» en el que valora su participación en la contienda: los líderes de la Segunda República, que contribuyeron con su mediocridad a preparar el escenario de la tragedia; los profetas del comunismo, el socialismo, el anarquismo y el fascismo, que se dedicaron a movilizar a sus huestes y azuzarlas con su retórica inflamada para luego lanzarlas a exterminar al enemigo; y las masas, que se dejaron engañar por los falsos profetas y dieron rienda suelta a sus instintos sanguinarios. Todos ellos, sin excepción, son culpables de haber empujado al país hacia el abismo y, por ello, son condenados por Baroja a entrar por la puerta estrecha que Bruegel pinta en El triunfo de la Muerte, una puerta tras la cual no parece haber más que muerte y desolación.

\section{FuENTES}

Baroja, Pío. 1939a. Comunistas, judíos y demás ralea. Valladolid: Cumbre.

Baroja, Pío. 1939b. «Una explicación». ABC, 24 de junio: 23.

Baroja, Pío. 1948. Obras Completas V. Madrid: Biblioteca Nueva. 
Baroja, Pío. 1949. Bagatelas de otoño. En Obras Completas VII, Pío Baroja,1231-1364. Madrid: Biblioteca Nueva.

Baroja, Pío. 1998. Ayer y hoy: Memorias. Madrid: Caro Raggio.

Baroja, Pío. 2005. La guerra civil en la frontera, ed. Fernando Pérez de Ollo. Madrid: Caro Raggio.

Baroja, Pío. 2006. Miserias de la guerra. Las Saturnales, ed. Miguel Sánchez-Ostiz. Madrid: Caro Raggio.

La Biblia. 1992. Madrid: La Casa de la Biblia.

Pemartín, José. 1937. «El espíritu y la historia». ABC de Sevilla, 13 de julio: 12.

Quintanar, Fernando Gallego de Chaves y Calleja, Marqués de. 1937a. «Deo Gratias». ABC de Sevilla, 28 de abril: 3-4.

Quintanar, Fernando Gallego de Chaves y Calleja, Marqués de. 1937b. «Franco, en los altares». ABC de Sevilla, 13 de febrero: 3-4.

Quintanar, Fernando Gallego de Chaves y Calleja, Marqués de. 1937c. «Franco, Regente de España». $A B C$ de Sevilla, 28 de julio: 3 .

Quintanar, Fernando Gallego de Chaves y Calleja, Marqués de. 1937d. «Muerte y resurrección». ABC de Sevilla, 22 de junio: 3-4.

Salaverría, José María. 1937. «Hacia la conquista de la paz por la victoria». ABC de Sevilla 28: 6.

\section{BiBLIOGRAFÍA CITADA}

Abellán, Manuel L. 1980. Censura y creación literaria en España (1939-1976). Barcelona: Península.

Andrés-Gallego, José y Antón M. Pazos, eds. 2001. Archivo Gomá. Documentos de la Guerra Civil. Vol. 1. Madrid: CSIC.

Andrés-Gallego, José y Antón M. Pazos, eds. 2004. Archivo Gomá. Documentos de la Guerra Civil. Vol. 6. Madrid: CSIC.

Barja, César. 1964. Libros y autores contemporáneos. New York: Las Américas.

Belmonte Serrano, José. 2006. «Pío Baroja, en su última vuelta del camino: textos sobre la Guerra Civil española». Cuadernos del Lazarillo: Revista Literaria y Cultural XXXI, 31: 46-54.

Bonn, Robert L. 2006. Painting Life: The Art of Pieter Bruegel, The Elder. New York: Chaucer P. Books.

Brummett, Barry. 1991. Contemporary Apocalyptic Rhetoric. New York: Praeger.

Caro Baroja, Pío. 2000. Crónica barojiana. La soledad de Pio Baroja. Madrid: Caro Raggio.

Chao Rego, Xosé. 2007. Iglesia y franquismo: 40 años de nacional-catolicismo (1936-1976). Santa Comba, A Coruña: TresCtres.

Collins, John J. 1979. «Introduction: Towards the Morphology of a Genre». Semeia: Apocalypse: The Morphology of a Genre 14: 1-20.

Collins, John J. 2016. The Apocalyptic Imagination: An Introduction to Jewish Apocalyptic Literature. Grand Rapids, Michigan: William B. Eerdmans.

Cunningham, Andrew y Ole Peter Grell. 2000. The Four Horsemen of the Apocalypse. Religion, War, Famine and Death in Reformation Europe. Cambridge: Cambridge University Press.

Díaz-Plaja, Fernando. 1976. La España franquista en sus documentos. Esplugas de Llobregat: Plaza \& Janés.

Elizalde, Ignacio. 1990. «Baroja y su ideología filosófica». 1616: Anuario de la Sociedad Española de Literatura General y Comparada VIII: 49-56. 
García de Juan, Miguel Ángel, ed. 1999. Desde el exilio (Los artículos inéditos publicados en La Nación de Buenos Aires, 1936-1943). Madrid: Caro Raggio.

García de Juan, Miguel Ángel, ed. 2001. Libertad frente a sumisión (Las colaboraciones periodísticas publicadas en España durante 1938). Madrid: Caro Raggio.

García de Juan, Miguel Ángel, ed. 2003. Los inéditos de Hoy (Los artículos publicados en Hoy de México). Madrid: Caro Raggio.

Gibson, Walter S. 1991. Pieter Bruegel the Elder: Two Studies. Lawrence, Kansas: Spencer Museum of Art - University of Kansas.

Gómez Marín, José A. 1974. «Los fascistas y el 98». Tiempo de Historia 1: 26-39.

Gracia, Jordi. 2004. La resistencia silenciosa. Fascismo y cultura en España. Madrid: Anagrama.

Granjel, Luis. 1992. El último Baroja. Bilbao: Sociedad Vasca de Historia de la Medicina.

Infantes, Víctor. 1997. Las Danzas de la Muerte. Génesis y desarrollo de un género medieval (Siglos XIII-XVII). Salamanca: Universidad.

Kant, Immanuel. 1987. «On the Ultimate Purpose that Nature Has as a Theleological System». En Critique of Judgement, trad. Werner S. Pluhar, 317-321. Indianapolis: Hackett.

Mainer, José Carlos. 2012. Pío Baroja. Madrid: Taurus.

Martín, Eutimio. 1975. «La actitud de Pío Baroja ante la guerra civil española». Cahiers $d u$ Monde Hispanique et Luso-brésilien 25: 119-133.

McGinn, Bernard. 1979. Visions of the End. Apocalyptic Traditions in the Middle Ages. New York: Columbia University Press.

Nora, Eugenio de. 1968. La novela española contemporánea (1898-1927). Madrid: Gredos.

Payne, Stanley. 1987. El régimen de Franco, 1936-1975. Madrid: Alianza.

Pérez Ferrero, Miguel. 1972. Vida de Pío Baroja. Madrid: Magisterio Español.

Pío XII. 1936. «Radiomensaje de Su Santidad Pío XII a los fieles de España». AAS 31: 151-154.

Pla y Deniel, Enrique. 1936. Las dos ciudades: Carta pastoral que dirige a sus diocesanos Enrique Pla y Deniel, Obispo de Salamanca, en 30 de septiembre de 1936. Salamanca: Calatrava.

Redondo, Gonzalo. 1993. Historia de la Iglesia en España. 1931-1939: La Guerra Civil, 1936-1939. Madrid: Rialp.

Reed, Kristin. 2012. «'A Palette of Portents”: Seamus Heaney and Pieter Bruegel». Quarterly Journal of Short Articles, Notes and Reviews 25 (4): 233-239.

Robert-Jones, Philippe and Françoise Robert-Jones. 1997. Bruegel. Paris: Flammarion.

Russell, David S. 1964. The Method and Message of Jewish Apocalyptic: 200 BC-AD 100. Philadelphia: Westminster.

Sánchez Ostiz, Miguel. 2000. Derrotero de Pío Baroja. Irún: Alberdania.

Sánchez Ostiz, Miguel. 2006. «El Madrid en guerra de Pío Baroja. Posfacio». En Miserias de la guerra. Las Saturnales, ed. Miguel Sánchez-Ostiz, 321-351. Madrid: Caro Raggio.

Sánchez Ostiz, Miguel. 2007. Tiempos de tormenta (Pío Baroja, 1936-1940). Pamplona: Pamiela.

Sinova, Justino. 2006. La censura de prensa durante el franquismo (1936-1951). Prólogo de Armando de Miguel. Barcelona: Mondadori.

Torrealdai, Joan Mari. 1998. La censura de Franco y los escritores vascos del 98. Donostia: Ttarttalo.

Trapiello, Andrés. 1994. Las armas y las letras. Barcelona: Planeta.

Fecha de recepción: 4 de junio de 2019.

Fecha de aceptación: 29 de octubre de 2019.

Revista de Literatura, 2021, vol. LXXXIII, n. ${ }^{\circ}$ 166, 503-526, ISSN: 0034-849X

https://doi.org/10.3989/revliteratura.2021.02.019 